\title{
1. Entrepreneurial network composition and the venture creation process: an empirical investigation
}

\author{
Tammi C. Redd, Michael A. Abebe and \\ Sibin Wu
}

\section{INTRODUCTION}

Numerous entrepreneurship scholars have explored the role of social networks in the entrepreneurship process (Katz and Gartner, 1988; Reynolds and Miller, 1992; Liao and Welsch, 2005). Still others have maintained focus on the acquisition of resources through social network contacts (Shane and Venkataraman, 2000; Aldrich and Zimmer, 1986). However, in the social networking literature pertaining to entrepreneurship, a disproportionate number of studies has presented a rather static view of social networks. Such a static view seems to overlook the fact that social networks are dynamic in nature, changing in structure and composition over time (Jack et al., 2008; Doreian and Stokman, 1997; Liao et al., 2005; Maurer and Ebers, 2006). In addition, the networking perspective of entrepreneurship has either focused on network characteristics such as strength of ties (Shane and Cable, 2002), embeddedness among the ties (Hite, 2005) and structure of the network (Human and Provan, 1997), or placed emphasis on developing networks such as networking ability (Semrau and Sigmund, 2010) and network practices (Anderson et al., 2010). While there is general understanding of entrepreneurship as a dynamic process at the nexus of individuals and opportunities (Shane and Venkataraman, 2000; Shane, 2003), how entrepreneurs maintain social networks at different stages of their venturing becomes crucial to business performance (Slotte-Kock and Coviello, 2010). To our knowledge, whether and why entrepreneurs' social network composition systematically varies across stages of the new venture formation has not been empirically examined. Our research intends to fill this research gap. Specifically, this study empirically investigates whether 
the number of entrepreneurs' strong and weak ties significantly differs across the opportunity identification, organizing and stability/growth stages of new venture formation. We draw from the social network (Adler and Kwon, 2002; De Carolis and Saparito, 2006) and resource dependence (Pfeffer and Salancik, 1978) theories to present a social network typology model that encompasses the network configuration that will cause fit between network contacts created and resources needed in creating a viable business. Further, based on the model, we derive and test hypotheses on the relationship between social network ties and stages of entrepreneurial process. Specifically, this research will address the following question: 'Do entrepreneurs' social network compositions differ significantly across different stages of the entrepreneurial process?'

The remainder of this chapter is organized as follows. A review of the literature detailing social network dynamics as well as the stages of entrepreneurship is presented, with related hypotheses on the relationships between social networking and the entrepreneurship process. We then summarize the literature on social network characteristics and the stages of the entrepreneurial process. Next, we propose and test hypotheses and discuss our results. The chapter concludes with limitations and suggestions for future research opportunities.

\section{LITERATURE REVIEW}

\section{Social Network Theory and Entrepreneurship}

Social networks, which often provide information leading to profitable opportunities, crucial resources and other supports, play an important role in entrepreneurial performance (Slotte-Kock and Coviello, 2010). The entrepreneurial endeavor is also a dynamic process full of uncertainty and hardships (Liao et al., 2005). Hence a stage model of venturing is deemed appropriate for such research (Shane and Venkataraman, 2000). Therefore we review literature related to social networking, resource acquisition and characteristics of different venturing stages.

Resource acquisition through social networking has been examined at many levels, both in the social networking literature in general and in entrepreneurship literature. In earlier studies, the basic structural features and theory of social networking were linked to entrepreneurship in terms of resources offered: knowledge and information transfer (Shan et al., 1994; Powell et al., 1996); capabilities and learning (McEvily and Zaheer, 1999); and explicit knowledge transfer (Uzzi and Lancaster, 2003). These studies confirm the value of examining relationships within a social network for 
a better understanding of resource acquisition and business outcomes (Semrau and Sigmund, 2010).

In the entrepreneurship literature on social networking we see a focus on the use of social ties in transitioning from conceptual stage of the venture to the actual launch of the business (Katz and Gartner, 1988; Reynolds and Miller, 1992). A summary of studies conducted in the past is given in Table 1.1.

As we can see in the literature overview, social networks are dynamic, changing structurally over time (e.g. Hite, 2005; Liao et al., 2005), but also must be diverse. Each network node or contact offers specific resources needed at different times (Doreian and Stokman, 1997). This suggests that entrepreneurs create and sever ties within the social network as necessary in order to acquire resources at any specific time (Granovetter, 1985; Kossinets and Watts, 2006). Those resources can be physical, financial, human and organizational, and may help a company gain sustainable competitive advantages (Barney, 1991). Contacts are called on when the sources they provide are appropriate (Doreian and Stokman, 1997). Social networks evolve over time; adaptation is key to obtaining necessary resources that are critical to successful new ventures.

Research has also found that those with heterogeneous networks, consisting of both strong and weak ties, are more likely to succeed with business start-up than those with homogeneous social networks (Renzulli et al., 2000). Furthermore, networks spanning multiple domains of social life apparently provide nascent entrepreneurs with greater access to multiple sources of information than do more homogeneous networks (ibid.).

\section{Resource Dependence Role of Social Networks}

The resource dependence theory (RDT) provides an important theoretical lens in the study of the role that network relationships play in the successful management of entrepreneurial ventures. This theory, first introduced by Pfeffer and Salancik (1978), has been widely used in the areas of organization theory, strategy and entrepreneurship research (Scherer and Lee, 2002; Casciaro and Piskorski, 2005; Hillman et al., 2009; Arthurs et al., 2009). RDT basically argues that organizations actively engage in responding to and shaping their immediate environment for the purpose of acquiring critical resources needed for achieving their objectives. As such, this theory assumes that (1) organizations are part of a broader environment that controls critical resources needed to achieve their objectives, and (2) organizations are capable of manipulating and changing the external environment in order to acquire resources. RDT is particularly relevant in the study of social networks and entrepreneurship for at least two major reasons. First, 


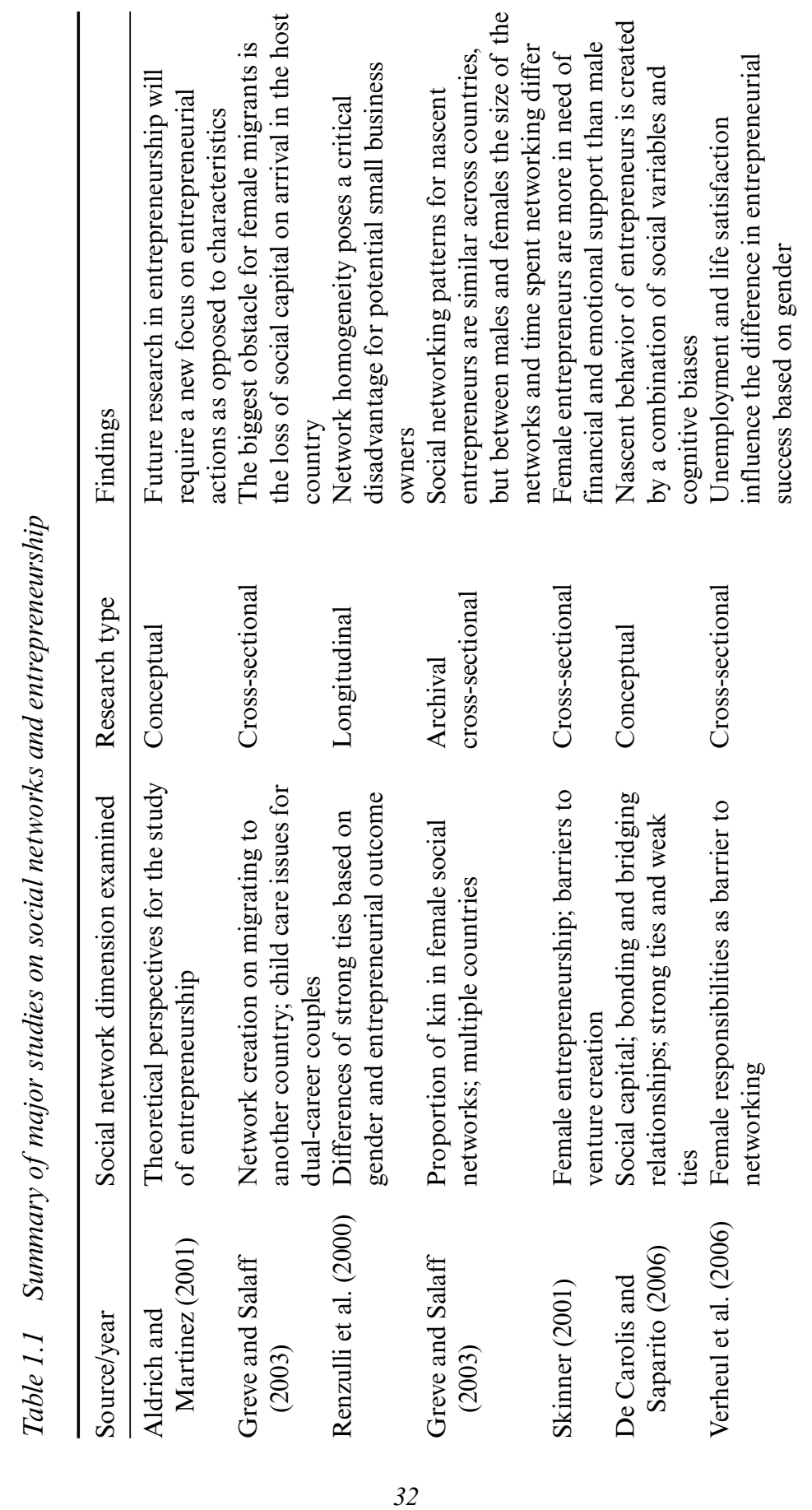



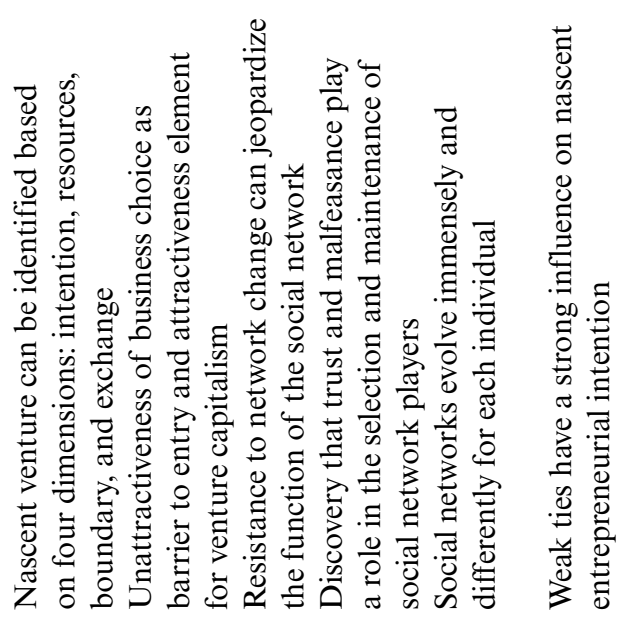

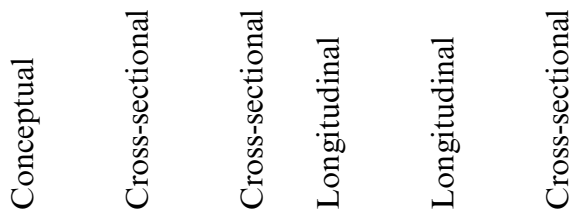

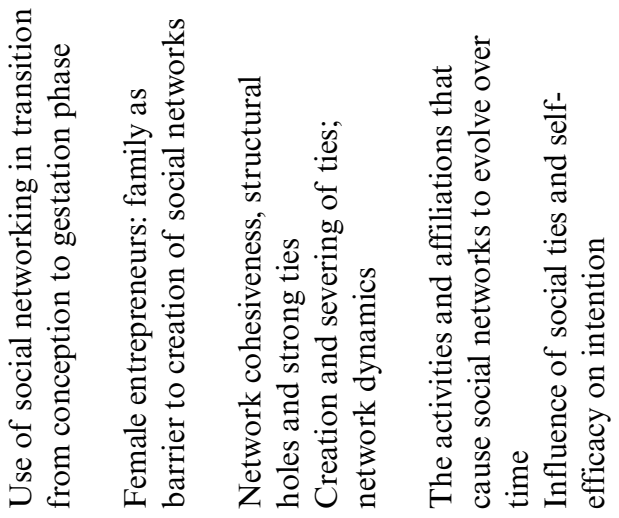

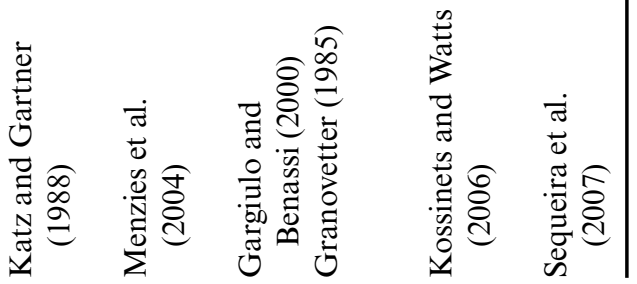


RDT emphasizes the importance of interdependence in inter-organizational relationships. As a number of studies have shown (e.g. Pfeffer, 1972; Hillman et al., 2000; Park et al., 2005), firms often operate in an interdependent external environment and as a result employ various tactics such as mergers and acquisitions, and board of director alliances in order to minimize their dependence on external actors. Second, RDT also emphasizes the importance of obtaining critical resources from external actors in the environment. These external actors may include venture capitalists, banks, investors and governmental agencies (Hillman et al., 2000; Hillman et al., 2009). In the entrepreneurship context, the emphasis on resource acquisition is particularly important in order to realize entrepreneurs' dreams of building successful and viable ventures (De Carolis and Saparito, 2006).

In this study, we combine the insights from RDT with those in social network theory to propose that social ties are important conduits in securing critical resources needed at the various stages of the entrepreneurial process (Adler and Kwon, 2002). In the following section, we briefly review the major stages of the entrepreneurial process.

\section{Stages of the Entrepreneurial Process}

There seems to be a fairly well-defined path of development for entrepreneurship, referred to as the entrepreneurship life cycle (Aldrich and Martinez, 2001). The beginning of an entrepreneurship venture is marked by opportunity identification, followed by an organizing stage in which resource acquisition is the key activity, and finally the stage of stability and growth once the venture has been launched (Greve and Salaff, 2003; Shane and Venkataraman, 2000). During this entrepreneurial process the creation of social capital is crucial to the successful launch and sustainability of a business venture.

\section{Opportunity identification stage}

The first stage in the venture creation process is opportunity identification. This stage is marked by the recognition of an idea in response to a perceived need for a product, service or innovative solution. Opportunities may arise as they are identified through search activities, just as often as they are discovered by those who searching for them; however; entrepreneurs must be alert to opportunities when they arise (Baron, 2006; Kaish and Gilad, 1991). Research has found that the opportunity identification stage is greatly influenced by potential social network relationships (Ozgen and Baron, 2007; Singh et al., 1999). It is during this stage that the entrepreneur discovers products or services that can be exploited (Casson, 1982; Shane and Venkataraman, 2000). 


\section{Organizing stage}

The second stage of the venture creation process is the organizing stage. Here the entrepreneur begins to assemble the resources required to begin the business venture. These may be tangible, in the form of property and financial capital (Katz and Gartner, 1988), or they can be intangible, in the form of credit, information or tacit knowledge (De Carolis and Saparito, 2006). The entrepreneur's goal during this stage is to identify the appropriate method to acquire all resources needed for the business start-up.

\section{Stability and growth stage}

The final stage of the venture creation process is the stage of stability and growth. It is hoped that by this point the entrepreneur has assembled resources so that not only have they been able to become business-active, but that this status is sustainable. For successful ventures, this stage is categorized by efficiency, growth and generation of revenue (Murphy et al., 1996). During this phase the entrepreneur focuses on long-term economic stability (Renski, 2009). It is also during this phase that entrepreneurs face the most risk, and those who are unable to attain stability and growth experience failed ventures. As a result, it is of utmost importance that relationships to actors within the social network are maintained so that access to crucial resources can be sustained over time.

\section{THEORY AND HYPOTHESIS DEVELOPMENT}

\section{Social Network Composition and Entrepreneurial Ventures}

Social network composition is often determined by examining the strength of ties, specifically the type of ties that are used in transitioning from the conceptual stage of the venture to the actual launch of the business (Katz and Gartner, 1988; Reynolds and Miller, 1992). It has also been suggested in the literature that social networks leading to successful business outcomes are those that maintain a balanced level of strong ties and weak ties (Greve and Salaff, 2003). The strength of these ties is determined by relationship characteristics such as intensity, time and reciprocity, according to De Carolis and Saparito (2006). In the entrepreneurship literature, strong ties have maintained the sociological definition developed in the early literature as family members, kin or those with whom there is a very strong relationship (Aldrich et al., 1995; Greve and Salaff, 2003). Scott (1998) defined kin to include parents, in-laws and spouses, while weak ties consist of friends, co-workers and any acquaintances outside of the family. Although most weak ties are casual acquaintances, Levin and 
Cross (2004) found that weak ties are still very important to the entrepreneur's social network because they often give the nascent entrepreneur access to different resources that may not be supplied by the strong ties of family members (Granovetter, 1973; Gargiulo and Benassi, 2000). The strength and mix of ties often determine whether the entrepreneur is being exposed to the information redundancy that is apparent in more homogeneous social networks that lack numerous information sources (Lin et al., 2001).

The relationships used within the social network change over time according to the need for appropriate resources to support each stage of the venture creation process. Relationships are created and severed as needed as entrepreneurs attempt to align the resources supplied by social network connections with resources needed by the entrepreneur at a particular time. This implies that different types of network ties supply varying types of resources.

As stated above, at the opportunity identification stage entrepreneurs face a large number of uncertainties, which need structural adjustments in order to cope successfully with change or varying requirements (Donaldson, 1996). Due to the dynamic nature at this stage, entrepreneurs need to find trustworthy advisors to guide them in exploring the right opportunities. In addition, uncertainties often raise business owners' stress levels, at which point their families' and close friends' emotional support becomes crucial. Thus strong ties are important when entrepreneurs probe for new ideas and seek psychological support.

At the organizing stage, however, entrepreneurs begin to exploit the chosen opportunity, registering the business, building a prototype, testing the markets and trying to achieve profitability (Gartner and Carter, 2004). These activities require entrepreneurs' skill and knowledge about internal operations and external markets so as to know where to gain the needed financial resources. To engage with so many activities, entrepreneurs' networks expand to include partners, government agencies, bankers, employees, customers and suppliers, among other stakeholders (Donaldson, 1996). Hence entrepreneurs have to manage many weak ties at this stage.

Lastly, when entrepreneurs have achieved the growth or stability stage, we expect that they will have developed strong ties with their stakeholders. Because strong ties require more trust, effort and intimacy (Granovetter, 1985), after years of operations of their businesses they will have chosen the right vendors, for example, and will have built a long, trustful relationship. Semrau and Sigmund (2010), for example, found that, compared with older firms, younger companies often lack organizational legitimacy. Therefore they have to compensate for the deficit by building larger 
networks. Established firms, however, have built strong ties with and gained the trust of their stakeholders. Based on the above argument, we examine following hypotheses:

Hypothesis 1.1: There is a significant difference in the number of entrepreneurs' strong ties among the three venture creation (opportunity identification, organizing and growth) stages.

Hypothesis 1.2: There is a significant difference in the number of entrepreneurs' weak ties among the three venture creation (opportunity identification, organizing and growth) stages.

\section{METHODOLOGY}

\section{Sample and Data Collection}

Data were collected from three groups of entrepreneurs in order to capture data at each of the three stages of the venture creation process (Greve and Salaff, 2003). A survey research design has been chosen for two reasons. First, even though some of the relationships tested in this study have never been tested before, the measurement items to be used in testing the hypotheses already exist. Second, a survey can easily reach a wide-ranging sample throughout the USA, making a large variety of entrepreneurs from different environmental contexts more accessible.

The target population for this study includes entrepreneurs throughout the USA who own or plan to own business ventures that can be classified as small businesses. The business owners included in the sample were identified both through Small Business Development Centers (SBDC) and also through an online panel. A detailed description of the respondents used in this study is presented in Table 1.2.

The survey design procedure used was based on the electronic survey design methods suggested by Dillman (2007). The response rate for electronic surveys is typically 28 percent, according to Dillman (2007), and a long survey can contribute to a lower response rate. However, the length of the survey used for this study should allow for the response rates to remain high as the entire questionnaire contains fewer than 40 questions.

In order to determine the correct sample size and effect size for the main study, a power analysis was performed with the pilot study data. The effect size 0.02 will be used in order to be conservative, as suggested by Cohen and Cohen (1983), since large effect sizes rarely occur in the 
Table 1.2 Sampling method across stages of entrepreneurship

\begin{tabular}{|c|c|c|c|}
\hline $\begin{array}{l}\text { Entrepreneurship } \\
\text { stage }\end{array}$ & $\begin{array}{l}\text { Sampling } \\
\text { source }\end{array}$ & Sample size & Description of participants \\
\hline $\begin{array}{l}\text { Opportunity } \\
\text { identification }\end{array}$ & $\begin{array}{l}\text { Small Business } \\
\text { Development } \\
\text { Centers and } \\
\text { online panel }\end{array}$ & 153 & $\begin{array}{l}\text { Prospective business owners } \\
\text { chosen for participation due } \\
\text { to a strong interest in starting } \\
\text { a business such as that } \\
\text { displayed by participation in } \\
\text { development activities offered } \\
\text { by a local Small Business } \\
\text { Development Center }\end{array}$ \\
\hline Organizing & Online panel & 149 & $\begin{array}{l}\text { New business owners chosen } \\
\text { for participation based } \\
\text { on being within the first } \\
\text { to fourth year of business } \\
\text { ownership }\end{array}$ \\
\hline $\begin{array}{l}\text { Stability and } \\
\text { growth }\end{array}$ & Online panel & 207 & $\begin{array}{l}\text { Established business owners } \\
\text { chosen for participation } \\
\text { based on being in business for } \\
5+\text { years }\end{array}$ \\
\hline
\end{tabular}

behavioral sciences. Cohen's sample and power tables were used in order to obtain the target sample size as suggested by Cohen (1988). With a target effect size of 0.02 and alpha $(\alpha)=0.05$, in order to obtain a power of approximately 0.80 a sample size of 392 is needed. In total, 2151 invitations to participate were extended. A total of 681 surveys were completed, 89 of which were unusable. The unusable surveys were classified as such because of instances in which respondents logged into the online survey but did not answer any questions or did not meet the age qualification to participate. Of the final of 592 responses, less than 1 percent were obtained by distributing face-to-face surveys; 6 percent were obtained from the state-level SBDCs; and 93 percent of the respondents were collected from Survey Monkey Audience. This procedure resulted in a 26.4 percent response rate.

\section{Survey Instrument}

A comprehensive measurement instrument was developed in order to measure strength of ties and stage in the venture creation process. Many of the items are borrowed from the Panel Study of Entrepreneurial Dynamics (PSED). The borrowed scales used in this study have typically measured 
using a 5-point Likert Scale. A 7-point Likert Scale was used here because 5-point Likert Scales are used less frequently in current research and because increasing the number of positions available on the Likert Scale increases the reliability and validity of the resulting data (Warner, 2008; Kaynak, 1997).

\section{Strength of ties}

Information on the strength of ties within the social network was gathered using an existing scale. The measurement items used are based on the work of Granovetter (1985). Since Granovetter's work, a measurement scale for strength of ties has been adapted by Marsden and Campbell (1984). Specifically, the respondents were asked not only to report the size of their social network used for business purposes, but also to supply information on the frequency and method of using this business contact either for resources or to discuss business matters in addition to the type of relationship (i.e. brother, work colleague etc.). A similar scale of questions was used in the PSED II; however, the PSED II scale measured strength of ties based on relationship status (Marsden and Campbell, 2004). The Marsden and Campbell scale was used in this study since it captures all the necessary dimensions of tie strength, including relationship type and frequency of contact.

\section{Venture creation stages}

The stage in the venture creation process is measured using adapted questions from the PSED II questionnaire (Gartner and Carter, 2004). This questionnaire, developed by Gartner et al. (2004), helps to gather information that will indicate activities in which the entrepreneur participates and the stage at which they function in the venture creation process. These questions remain unchanged from those used in the PSED I. Together these measurements are among the most used measurement items for capturing venture creation stage data (Frid et al., 2011). Gartner et al. (2004) categorized business outcomes of entrepreneurs by length of activity, specifically by asking in what month and year the business came into existence. Similar categorizations were used in this study in order to classify respondents into one of four groups based on the literature presented in the literature review. The respondents will be classified into the following categories: (1) have not started business yet; (2) have been in business 1 to 5 years; (3) have been in business 5 to 10 years; and (4) have been in business 10 or more years. These categories will allow identification of the opportunity identification, organizing and growth/stability stages. 


\section{DATA ANALYSIS AND RESULTS}

\section{Non-response Bias}

Typically, self-report surveys are distributed by mail; however, for this study the survey responses were collected using intercept and electronic surveys. In survey research it is always a concern that a non-response bias exists in the data, resulting in the exclusion of one or more groups (Singleton and Straits, 2005). For this study, non-response bias was tested using Hotelling's T. Early and late responders were sorted by date and used as a proxy for responder and non-responder respectively. The Hotelling's- $\mathrm{T}^{2}$ statistic indicated that there was no significant difference between early and late responders (Oppenheim, 1992).

\section{Strength of Ties}

According to Hypotheses 1 and 2, it was expected that there would be a difference in the number of strong ties and the number of weak ties between different stages of the venture creation process. The ANOVA test results are presented in Table 1.3. The ANOVA test for Hypothesis 1 rendered a non-significant result, lending no support for Hypothesis 1 . Thus there is no significant difference in the number of strong ties possessed across the three venture creation stages. On the other hand, in testing Hypothesis 2, a significant difference was found between the three stages of the venture creation process in the number of weak ties possessed in the social network. Thus Hypothesis 2 is supported.

\section{Supplemental Analysis of Network Composition across Venture Stages}

Given the significant differences in the number of entrepreneurial weak ties across the three entrepreneurial stages, we conducted a follow-up analysis to understand the specific differences among the three stages. A least significant difference (LSD) post hoc analysis was conducted in order to test for random differences among the three stages of entrepreneurship. The results of the analysis are shown in Table 1.4. The post hoc analysis shows that, for the significant hypothesis, the only two stages that do not differ at $\alpha=0.05$ in the LSD analysis are the organizing stage and the growth and stability stage. However, through further analysis of the means plots for the total of weak ties for the sample, it is evident that, with each stage of the venture creation process, the total of weak ties has an upward trend. 


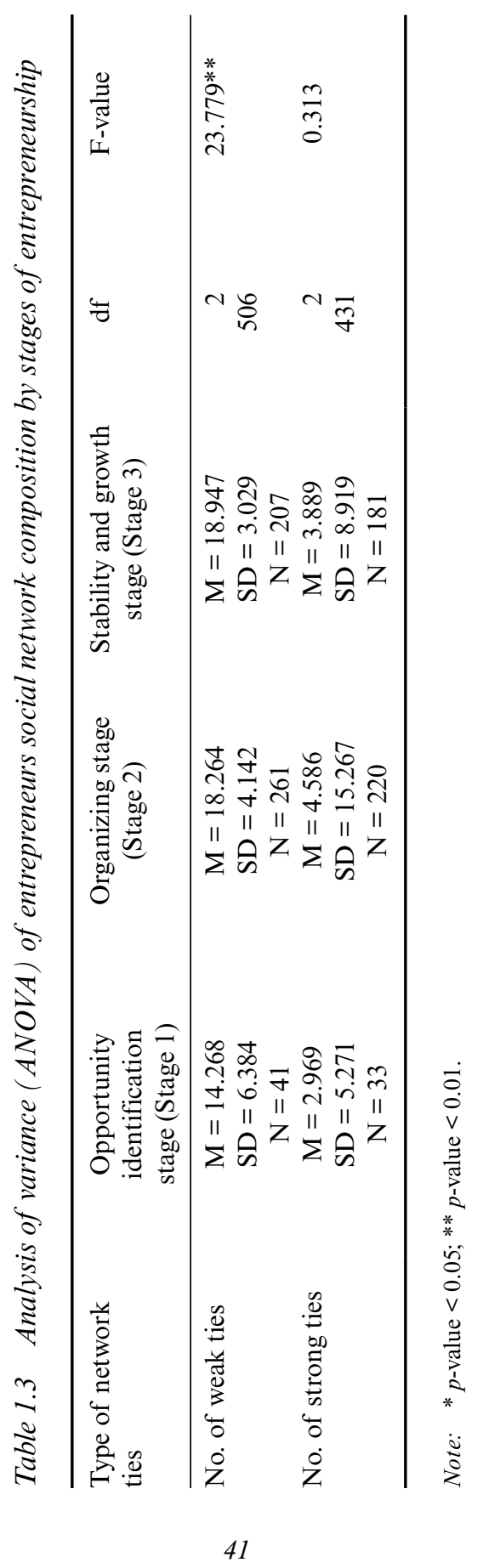


Table 1.4 A Tukey HSD post hoc analysis of the mean differences in social network composition across stages of entrepreneurship

\begin{tabular}{lllll}
\hline $\begin{array}{l}\text { Type of social } \\
\text { network composition }\end{array}$ & \multicolumn{2}{c}{$\begin{array}{c}\text { Venture creation } \\
\text { stages }\end{array}$} & $\begin{array}{c}\text { Mean } \\
\text { differences }\end{array}$ & $\begin{array}{c}\text { Standard } \\
\text { error }\end{array}$ \\
\hline No. of strong ties & Stage 1 vs & Stage 2 & -1.617 & 2.356 \\
& & Stage 3 & -0.919 & 2.389 \\
\multirow{2}{*}{ No. of weak ties } & Stage 2 vs & Stage 3 & 0.697 & 1.266 \\
& Stage 1 vs & Stage 2 & $-3.966^{* *}$ & 0.667 \\
& & Stage 3 & $-4.679^{* *}$ & 0.679 \\
& Stage 2 vs & Stage 3 & 0.682 & 0.369 \\
\hline
\end{tabular}

Notes:

Stage $1=$ opportunity identification; Stage $2=$ organizing; Stage $3=$ stability and growth.

$* p$-value $<0.05 ; * * p$-value $<0.01$.

\section{DISCUSSION}

Social network theory suggests that relationships, either personal or interfirm, may facilitate acquisition of information and resources. Hite (2005) and Jack (2010) concluded that network relationships provide enterprises with channels, bridges and ways to access opportunities and resources, two critical factors for entrepreneurial success. Johannisson (1988) proposed that the entrepreneur is a networker where he/she utilizes interfirm relationships to access resources so as to gain competitive advantages. However, due to time and budget constraints, entrepreneurs have to manage those relationships. Specifically, when to build strong ties and when to maintain weak ties become crucial to business owners.

The current research aims to find an answer to the above question. We employed social network theory to compare the composition of weak ties and strong ties during the entrepreneurial process, from opportunity identification stage, to organization stage, to growth/stability stage.

Our first hypothesis states that, during the three stages of entrepreneurial venturing, a variation in strong ties should be expected. However, the results do not support what we predicted. Our finding indicates that strong ties seem to be stable over the three phases, from an average of 3.0 strong ties at opportunity identification, to 4.6 at organizing, to 3.9 at growth/ stability. We argue that the non-finding may be due to the following. First, entrepreneurs may view only family and close friends as strong ties, and, therefore, their family members whom they can trust and seek advice from remain stable over years. Second, entrepreneurs build ties and also sever 
ties at the same time. Strong ties may be more likely to be retained rather than severed throughout the venture creation process. Third, strong ties often lend emotional support to entrepreneurs and require time and intimacy. Therefore it is difficult for entrepreneurs to sustain too many critical friendships (Gladwell, 2010).

We also predicted that weak ties would vary across different stages of the entrepreneurial process. The analysis lends support to our hypothesis. We found that entrepreneurs build and maintain more and more weak ties along with their venturing effort. This particular finding is of value to social network research for the following reasons. First, the measures for social network ties were developed before the introduction of the Internet and Internet-ready devices (Boase et al., 2006). The proliferation of Internet access through the use of even mobile devices has made access to new network connection and the creation of weak ties easier than it has ever been before (Washington, 2011). The second reason has to do with the classic definition of weak ties, categorizing these online ties as distant and as contacted less frequently. The availability of the Internet in most areas has now made it possible for someone who has never been met face to face to be a strong tie, when in the past they would have been classified as a weak tie because of simple acquaintance. Third, when entrepreneurs progress with their business venturing, their networking ability is enhanced, which leads to more and bigger networks (Semrau and Sigmund, 2010).

Pfeffer and Salancik (1974) examined resource dependency theory (RDT) at the organizational subunit level. If we examine the nodes or connections within the social network as subunits, we can see how network relationships arise and how that subunit's resources are used once acquired. Perrow (1970) argued that all subunits are not equally influential, and Thompson (1967) suggested that the subunit that is best able to cope with contingency will be dominant. Perhaps this means, in terms of social network connections, that the influence of each relationship will vary, and some connections will become dominant because of the resources they offer. Relationships that contribute the most scarce and critical resources for the organization will be the most significant subunit, with a relationship tie that will be maintained throughout the growth and stability stage. Pfeffer and Salancik (1974) also found that these more powerful subunits had more outside support, giving them more influence over internal allocation of resources. For an entrepreneur, this may mean that network ties that remain dominant may increase the number of relational ties within a social network.

Perhaps a larger effort must be made to become more active in the local business community, in addition to attending local chamber of commerce 
events, small business development centers, networking events and local charity events held by local business owners. These types of activity allow entrepreneurs to maintain valuable relationships as well as develop new ones.

The linkage of social network theory to the field of entrepreneurship certainly suggests implications for future research that will expand knowledge of the field about resource acquisition and the importance of network ties in the entrepreneurial process. Although the scope of this chapter does not allow a more detailed exploration of network dynamics, the study does, however, give a better understanding of the resource acquisition process and the ability to overcome the already established social networking barriers to venture creation. Many entrepreneurial business decisions are shaped by social relationships, and creating a sustainable business venture depends heavily on the resources and contacts gained through these relationships (Greve and Salaff, 2003).

Future research should address this phenomenon from a longitudinal standpoint, or perhaps through case studies to enable description of the network orientation typologies with more precision. We must also consider that each entrepreneur, based on personal differences and strategic approaches, along with variation in environmental constraints and different levels of networking ability, faces different challenges that have not yet been captured in the entrepreneurial social networking literature. Future research could also address specific network orientations that cause ventures to fail.

\section{CONCLUSION}

This research investigates the dynamics of the structural composition of social networks during different stages of the venture creation process. Specifically, we have examined the possession of strong and weak ties during these different stages. This study was conducted in hopes of furthering the study of entrepreneurs' dynamic social networks. We found that no differences exist across the stages of venture creation in terms of strong ties, as these relationships may be easier to maintain over the long term. We also found that the number of weak ties in an entrepreneur's social network tends to increase as the entrepreneur passes through the stages of entrepreneurial development. This perhaps suggests that weak ties offer resources that cannot be obtained through maintenance of strong network ties. We hope our findings will enhance the understanding of the role social network composition plays in various stages of new venture formation. 


\section{REFERENCES}

Adler, P.S. and S.W. Kwon (2002), 'Social capital: prospects for a new concept', Academy of Management Review, 27(1), 17-40.

Aldrich, Howard, Amanda Elam and Pat Ray Reese (1995), 'Strong ties, weak ties, and strangers: do women business owners differ from men in their use of networking to obtain assistance?', in Sue Birley and Ian MacMillan (eds), Entrepreneurship in a Global Context, London: Macmillan, pp. 1-25.

Aldrich, Howard and Martha Martinez (2001), 'Many are called, but few are chosen: an evolutionary perspective for the study of entrepreneurship', Entrepreneurship Theory and Practice, Summer: 41-56.

Aldrich, Howard and Catherine Zimmer (1986), 'Entrepreneurship through social networks', in Donald Sexton and Raymond Smilor (eds), The Art and Science of Entrepreneurship, Cambridge, MA: Ballinger, pp. 1-23.

Anderson, Alistair, Sarah Dodd and Sarah Jack (2010), 'Network practices and entrepreneurial growth', Scandinavian Journal of Management, 26: 121-33.

Arthurs, Jonathan, Lowell Busenitz, Robert Hoskisson and Richard Johnson (2009), 'Firm-specific human capital and governance in IPO firms: addressing agency and resource dependence concerns', Entrepreneurship Theory and Practice, 33(4): 845-65.

Barney, Jay (1991), 'Firm resources and sustained competitive advantage', Journal of Management, 17: 99-120.

Baron, Robert (2006), 'Opportunity recognition as pattern recognition: how entrepreneurs "connect the dots" to identify new business opportunities', Academy of Management Perspectives, 20:104-19.

Boase, Jeffrey, John Horrigan, Barry Wellman and Lee Rainie (2006), 'The strength of Internet ties', Pew Internet and American Life Project. Accessed May 20, 2009. http://www.pewInternet.org/pdfs/PIP_Internet ties.pdf.

Casciaro, Tiziana and Mikolaj Piskorski (2005), 'Power imbalance, mutual dependence, and constraint absorption: a closer look at resource dependence theory', Administrative Science Quarterly, 50(2): 167-99.

Casson, Mark (1982), The Entrepreneur, Totowa, NJ: Barnes \& Noble.

Cohen, Jacob (1988), Statistical Power Analysis for the Behavioral Sciences, 2nd edn, Hillsdale, NJ: Lawrence Erlbaum Associates.

Cohen, Jacob and Patricia Cohen (1983), Applied Multiple Regression/Correlation Analysis for the Behavioral Sciences, 2nd edn, Hillsdale, NJ: Lawrence Erlbaum Associates.

De Carolis, Donna and Patrick Saparito (2006), 'Social capital, cognition, and entrepreneurial opportunities: a theoretical framework', Entrepreneurship Theory and Practice, 30(1): 41-56.

Dillman, Donald (2007), Mail and Internet Surveys: The Tailored Design Method 2007 Update with New Internet, Visual, and Mixed-mode Guide, Hoboken, NJ: John Wiley \& and Sons.

Donaldson, L. (1996), 'The normal science of structural contingency theory', in Stewart Clegg, Cynthia Hardy and Walter Nord (eds), Handbook of Organizational Studies, London: Sage Publications, pp. 57-76.

Doreian, Patrick and Franz Stokman (1997), 'The dynamics and evolution of social networks', in Sue Birley and Ian MacMillan (eds), Social Network Evolution, London: Macmillan, pp. 17-18. 
Frid, Casey, S. Gordon and Per Davidsson (2011), 'Publications based on the Panel Study of Entrepreneurial Dynamics', St Louis, MO: The Kauffman Foundation.

Gargiulo, Martin and Mario Benassi (2000), 'Trapped in your own net? Network cohesion, structural holes, and the adaptation of social capital', Organization Science, 11(2): 183-96.

Gartner, William and Nancy Carter (2004), 'Overview: the startup process', in William B. Gartner, Kelley G. Shaver, Nancy M. Carter and Paul D. Reynolds (eds), Handbook of Entrepreneurial Dynamics, Thousand Oaks, CA: Sage Publications, pp. 237-43.

Gladwell, Malcolm (2010), 'At 42', The New Yorker, October 4. http://www. newyorker.com/2010/10/04/101004fa_fact_gladwell.

Granovetter, Mark (1973), 'The strength of weak ties', American Journal of Sociology, 78: 1360-80.

Granovetter, Mark (1985), 'Economic action and social structure: a theory of embeddedness', American Journal of Sociology, 91(3): 481-510.

Greve, Arent and Janet Salaff (2003), 'Social networks and entrepreneurship', Entrepreneurship Theory and Practice, Fall: 1-22.

Hillman, Amy, Albert Cannella and Ramona Paetzold (2000), 'The resource dependence role of corporate directors: strategic adaptation of board composition in response to environmental change', Journal of Management Studies, 37(2): 235-55.

Hillman, Amy, Michael Withers and Brian Collins (2009), 'Resource dependence theory: a review', Journal of Management, 35(6): 1404-27.

Hite, Julie (2005), 'Evolutionary processes and paths of relationally embedded network ties in emerging entrepreneurial firms', Entrepreneurship Theory and Practice, 29(1): 113-44.

Human, Sherrie and Keith Provan (1997), 'An emergent theory of structure and outcomes in small-firm strategic manufacturing networks', Academy of Management Journal, 40(2): 368-403.

Jack, Sarah (2010), 'Approaches to studying networks: implications and outcomes', Journal of Business Venturing, 25(1): 120-37.

Jack, Sarah, Sarah Drakopolou Dodd and Alistair Anderson (2008), 'Change and the development of entrepreneurial networks over time: a processual perspective', Entrepreneurship and Regional Development, 20(2): 125-59.

Johannisson, Bengt (1988), 'Business formation: a network approach', Scandinavian Journal of Management, 4(3-4): 83-99.

Kaish, Stanley and Benjamin Gilad (1991), 'Characteristics of opportunities search of entrepreneurs versus executives: sources, interests, general alertness', Journal of Business Venturing, 6: 45-61.

Katz, Jerome and William Gartner (1988), 'Properties of emerging organizations', Academy of Management Review, 13: 429-41.

Kaynak, Hale (1997), Total Quality Management and Just-in-time Purchasing: Their Effects on Performance of Firms Operating in the U.S., New York: Garland Publishing.

Kossinets, Gueorgi and Duncan Watts (2006), 'Empirical analysis of an evolving social network', Science, 311(5757): 88-90.

Levin, D.Z. and R. Cross (2004), 'The strength of weak ties you can trust: the mediating role of trust in effective knowledge transfer', Management Science, 50: $1477-90$.

Liao, Jianwen and Harold Welsch (2005), 'Roles of social capital in venture 
creation: key dimensions and research implications', Journal of Small Business Management, 43: 345-62.

Liao, Jianwen, Harold Welsch and Wee-Liang (2005), 'Venture gestation paths of nascent entrepreneurs: exploring the temporal patterns', Journal of High Technology Management Research, 16: 1-22.

Lin, Nan (2001), 'Building a network theory of social capital', in Nan Lin, Karen Cook and Ronald Burt (eds), Social Capital, New York: Gruyter, pp. 3-31.

Marsden, Peter and Karen Campbell (1984), 'Measuring tie strength', Social Forces, 63: 482-501.

Maurer, Indre and Mark Ebers (2006), 'Dynamics of social capital and their performance implications: lessons from biotechnology start-ups', Administrative Science Quarterly, 51: 262-92.

McEvily, Bill and Akbar Zaheer (1999), 'Bridging ties: a source of firm heterogeneity in competitive capabilities', Strategic Management Journal, 20(12): 1133-56.

Menzies, T.V., M. Diochon and Y. Gasse (2004), 'Examining venture-related myths concerning women entrepreneurs', Journal of Developmental Entrepreneurship, 9: 89-107.

Murphy, Gregory, Jeff Trailer and Robert Hill (1996), 'Measuring performance in entrepreneurship literature', Journal of Business Research, 36: 15-23.

Oppenheim, A.N. (1992), Questionnaire Design, Interviewing and Attitude Measurement, London: Pinter.

Ozgen, Eren and Robert Baron (2007), 'Social sources of information in opportunity recognition: effects of mentors, industry networks, and professional forums', Journal of Business Venturing, 22: 174-92.

Park, Namgayoo, John Mezias and Jaeyong Song (2005), 'Before and after the technology sector crash: the effect of environmental munificence on stock market response to alliances of e-commerce firms', Strategic Management Journal, 26(11): 987-1007.

Perrow, C. (1970), Organizational Analysis: A Sociological View, London: Tavistock Publications.

Pfeffer, J. (1972), 'Merger as a response to organizational interdependence', Administrative Science Quarterly, 382-94.

Pfeffer, Jeffrey and Gerald Salancik (1974), 'The bases and use of power in organizational decision-making: the case of a university', Administrative Science Quarterly, 19(4): 453-73.

Pfeffer, Jeffrey and Gerald Salancik (1978), The External Control of Organizations: A Resource Dependence Perspective, Stanford, CA: Stanford Business Press.

Powell, Walter, Kennthus Koput and LaurelSmith-Doerr(1996), 'Interorganizational collaboration and the locus of innovation: networks of learning in biotechnology', Administrative Science Quarterly, 41(1): 116-45.

Renski, Henry (2009), 'New firm entry, survival, and growth in the United States: a comparison of urban, suburban and rural areas', Journal of the American Planning Association, Winter: 60-77.

Renzulli, Linda, Howard Alrdrich and James Moody (2000), 'Family matters: gender, networks, and entrepreneurial outcomes', Social Forces, 79(2): 523-46.

Reynolds, Paul and Brenda Miller (1992), 'New firm gestation: conception, birth, and implications for research', Journal of Business Venturing, 7: 405-17.

Scherer, P.D. and K. Lee (2002), 'Institutional change in large law firms: a resource dependency and institutional perspective', Academy of Management Journal, 45(1): 102-19. 
Scott, John (1988), 'Social network analysis', Sociology, 22: 109-27.

Semrau, Thorsten and Stefan Sigmund (2010), 'The impact of networking ability on new venture performance', presented at Academy of Management Best Paper Proceedings 2010, August 1-6.

Sequeira, J., S. Mueller and J. McGee (2007), 'The influence of social ties and self efficacy in forming entrepreneurial intentions and motivating nascent behavior', Journal of Developmental Entrepreneurship, 12: 275-93.

Shan, Weijian, Gregory Walker and Bruce Kogut (1994), 'Interfirm cooperation and startup innovation in the biotechnology industry', Strategic Management Journal, 15(5): 387-94.

Shane, S.A. (2003), A General Theory of Entrepreneurship: The IndividualOpportunity Nexus, Cheltenham, UK and Northampton, MA. USA: Edward Elgar Publishing.

Shane, Scott and Daniel Cable (2002), 'Network ties, reputation and the financing of new ventures', Management Science, 48: 364-381.

Shane, Scott and Sankaran Venkataraman (2000), 'The promise of entrepreneurship as a field of research', Academy of Management Review, 25: 217-26.

Singh, R.P., G.E. Hills, G.T. Lumpkin and R.C. Hybels (1999), 'The entrepreneurial opportunity recognition process: examining the role of self-perceived alertness and social networks', in Academy of Management (ed.), Academy of Management Proceedings, pp. G1-G6.

Singleton, Royce and Bruce Straits (2005), Approaches to Social Research, 4th edn, New York: Oxford University Press.

Skinner, S. (2001), 'Female entrepreneurs in the retail trade: a study of personal and professional traits as they impact on business environments', Journal of Small Business Management: 183-95.

Slotte-Kock, Susanna and Nicole Coviello (2010), 'Entrepreneurship research on network processes: a review and ways forward', Entrepreneurship Theory and Practice, 35: 31-56.

Thompson, James (1967), Organizations in Action: Social Science Bases of Administrative Theory, New York: McGraw-Hill.

Uzzi, Brian and Ryon Lancaster (2003), 'Relational embeddedness and learning: the case of bank loan managers and their clients', Management Science, 49: 383-99.

Verheul, I., A. Van Stel and R. Thurik (2006), 'Explaining female and male entrepreneurship at the country level', Entrepreneurship \& Regional Development, March: 151-83.

Warner, Rebecca (2008), Applied Statistics: From Bivariate through Multivariate Techniques, Los Angeles, CA: Sage Publications.

Washington, Jesse (2011), 'For minorities, new digital divide seen', USA Today, January 1. http://www.usatoday.com. 